MERAWAT RUANG BERSAMA DALAM PERBEDAAN

Liliya F. K. Wetangterah

KITAB TAURAT YOSIA

Oscard L. Tobing

EKSISTENSI PENGANUT ALUK TODOLO DI PA'BUARAN, TANA TORAJA

Tri Oktavia Hartati Silaban

KONSELING PASTORAL

Yonatan Sumarto

PERANAN AGAMA KRISTEN DALAM MENGHADAPI KONFLIK

AGAMA DI INDONESIA

Syani Bombongan Rante Salu

Marsi Bombongan Rante Salu

KEPEMIMPINAN PUBLIK

Reymond Pandapotan Sianturi

KURIKULUM BERWAWASAN PLURALISME

Yusak B. Setyawan

MARI BERSAMA (KITA) MEMBANGUN KAMPUNG GLOBAL

Aleksander Mangoting ANALISIS KINERJA DOSEN DALAM MELAKSANAKAN

TRI DHARMA BAGI PENINGKATAN MUTU PERGURUAN TINGGI

Irna Allorundun

MEMBANGUN SEKOLAH UNGGULAN

I Made Suardana

KEMENTERIAN AGAMA RI SEKOLAH TINGGI AGAMA KRISTEN (STAKN) TORAJA 
Jurnal Marampa', Vol. 1, 2017 / ISSN: 2086-2709

\title{
Konseling Pastoral : Analisis Efektifitas Konseling dalam Meningkatkan Pertumbuhan Gereja Oleh: Yonatan Sumarto
}

\author{
Sekolah Tinggi Agama Kristen Negeri (STAKN) Toraja \\ J1. Poros Makale-Makassar Km. 11,5 Mengkendek, Kabupaten Tana Toraja, Sulawesi Selatan \\ Email: yonatansumarto@yahoo.co.id
}

\begin{abstract}
This paper deals with one of the most pressing needs of today that the Church should do. Members of the congregation desperately need counseling services to answer the problems they face in their lives in private. Thus, it is necessary to establish a counseling service within the Church, with the aim of helping, guiding, directing, guiding members out of the problems they face, thereby resulting in a better life cycle.

Today many members of the congregation are troubled both in the family, resulting in their family life away from worship, alcoholic beverages and marriage of different religions, to see such things there needs to be counseling services present in the church.

Keywords: Pastoral Counseling, Church Growth.
\end{abstract}

\section{PENDAHULUAN}

Dalam menjalankan kehidupan ini tentu banyak hal yang dihadapi oleh setiap orang, apa lagi pada dewasa ini tantangan demi tantangan yang ada di depan mata membuat setiap insan manusia merasa gelisah bahkan takut untuk menghadapinya. Hal tersebut menyebabkan munculnya persoalanpersoalan yang sedemikian banyak dan rumit.

Untuk menjawab persoalaan tersebut perlu adanya teori Penggembalaan, apabila pelayanan perkunjungan penggembalaan dijalankan terjadilah suatu perubahan di dalam jemaat tersebut, dalam buku pelayanan Penggembalaan yang Ideal diungkapkan bahwa,

Penggembalaan tak dapat dilakukan dari jarak jauh tanpa hubungan pribadi, seperti dengan pelayanan telepon yang menjawab secara otomatis, berita-berita yang dikeluarkan dari komputer, surat-surat yang bersifat umum. Artinya bahwa pelayanan pastoral tak dapat dilakukan lewat surat menyurat, atau secara mekanis, karena penggembalaan bersifat pribadi. Penggembalaan bukanlah percakapan umum, tetapi merupakan perjumpaan antar pribadi yang memungkinkan lebih banyak keterbukaan pribadi. ${ }^{1}$

\footnotetext{
${ }^{1}$ Bruce Larson, Paul Anderson \& Doug Self, Pelayanan Penggembalaan yang Ideal (Malang: Gandum Mas, 1996), 17.
} 
Dalam pelayanan penggembalaan perkunjungan merupakan yang sangat penting bagi anggota jemaat, melalui pelayanan perkunjungan gembala jemaat harus mengetahui keadaan dan kebutuhan setiap anggota jemaatnya yang ia layani.

Namun kenyataan yang terjadi ada gembala kurang memperhatikan anggota jemaat yang ia layani sehingga banyak anggota jemaat yang memiliki problem hidup, sehingga mengakibatkan diri mereka tidak mengikuti kegiatan ibadah/persekutuan yang dilaksanakan. Karena mereka diperhadapkan dengan berbagai persoalan dalam hidup mereka. Dalam kehidupan berjemaat ada banyak masalah yang dihadapi oleh keluarga Kristen, baik masalah dalam rumah tangga, masalah kehidupan anak yang minum-minuman beralkohol, narkoba, isap lem, pernikahan beda agama, kumpul kebo, maupun masalah pribadi dan lain-lainnya. Dengan keberadaan jemaat yang demikian memerlukan suatu pengajaran pembinaan rohani untuk mengatasi masalah yang mereka hadapi.

Seorang gembala yang sudah memiliki pengetahuan tentang kebenaran firman Tuhan ia harus menerapkan apa yang Paulus katakan, "Dialah yang kami beritakan, apabila tiap-tiap orang kami nasihati dan tiap-tiap orang kami ajari dalam segala hikmat, untuk memimpin tiap-tiap orang kepada kesempurnaan dalam Kristus" (Kolose 1:28). Kalau kebenaran firman Tuhan ini diterapkan oleh seorang gembala jemaat untuk jemaatnya, akan terjadi tranformasi bagi jemaatnya dan gereja. Sebaliknya kalau ini tidak di jalankan maka bergeserlah kebenaran firman Tuhan yang berakibat fatal.

Penulis mencoba untuk mengambil teori lain yang bisa menjawab persoalaan yang di hadapi oleh jemaat tersebut adalah teori konseling, Jermia Djadi mengatakan yakni;

Pertama, menolong seseorang untuk menemukan akar permasalahan yang sedang dihadapi. Kedua, menolong seseorang untuk memecahkan permasalahannya dan menemukan jalan keluar dari permasalahan itu. Ketiga, menolong seseorang untuk memenuhi kebutuhannya, melalui informasi, dorongan, nasihat, dan penghiburan. Keempat, menolong seseorang agar mampu mengambil keputusan sendiri, misalnya mengubuh tingkah laku, sikap, dan pandangan tertentu. Kelima, menolong seseorang untuk terus bertembuh menuju kedewasaan penuh dalam Kristus. ${ }^{2}$

Jadi, prinsip yang sangat penting dalam pelayanan konseling penggembalaan adalah membimbing, menuntun, mendampingi dan mengarahkan anggota jemaat yang memiliki problem maupun tidak (secara holistik) sehingga kehidupan kerohanian mereka semakin dewasa di dalam Tuhan.

${ }^{2}$ Jermia Djadi, “Peran Pastoral Konseling Bagi Pertumbuhan Jemaat” (Ujung Pandang: Makalah, 1994), 5. 


\section{PEMBAHASAN}

\section{Dasar Konseling}

Semua praktik konseling dalam Alkitab yang bertindak sebagai inisiator ialah Allah sendirilah yang datang mencari manusia dan kemudian Ia berinisiatif menolong manusia sebagai konseli dalam berbagai bentuk dan persoalan dalam hidup terutama yang menyangkut mengenai dosa. Persoalan utama yaitu dosa itulah yang dihadapi oleh manusia sebagai konseli dan inilah yang dijawab oleh Allah secara langsung dan memberikan jalan kepada manusia untuk menemukan jalan kelepasan dari persoalan yang dihadapi oleh insan-Nya itu sendiri, dan memberikan perhatian kepada manusia dalam suatu jalan bimbingan yang penuh kasih sayang dan kelembutan agar manusia yang dibimbing itu secara langsung merasakan kebahagiaan dalam menjalankan kehidupan dalam dunia. Firman Tuhan dalam Mazmur 23:2-3 berkata, "Ia membaringkan aku di padang yang berumput hijau, Ia membimbing aku ke air yang tenang, Ia menyegarkan jiwaku. Ia menuntun aku di jalan yang benar oleh karena nama-Nya."

Dalam upaya menjelaskan bagaimana praktik konseling dalam Alkitab baik Perjanjian Lama dan Perjanjian Baru tentu tidak semua peristiwa atau kisah dalam kitab suci dapat dicantumkan dalam tulisan ini namun ada beberapa hal saja yang diambil sebagai contoh bagaimana peristiwa konseling itu sebagai dasar dalam mengembangkan pelayanan konseling pada dewasa ini.

Hana yang terdapat dalam I Samuel 1, dapat disebut sebagai kasus stres yang sangat berat yang berakibat dapat menjurus kepada depresi. Hana mengungkapkannya kepada Imam Eli, "Bukan, tuanku, aku seorang perempuan yang sangat bersusah hati, anggur ataupun minuman yang memabukkan tidakku minum, melainkan aku mencurahkan isi hatiku di hadapan Tuhan .... Aku sangat bersusah hati aku" (sangat/besarnya) cemas, dan sakit hati (I Sam 1:15-16). Stres Hana disebabkan oleh harga dirinya direndahkan oleh madunya, madunya dengan sengaja menciptakan suasana dan kata-kata yang menimbulkan sakit hati yang mendalam terhadap Hana bahkan menimbulkan kegusaran dari Hana (ayat 6). Persoalan ini dialami oleh Hana selama bertahun-tahun (ayat 7), itulah sebabnya Hana menjadi sangat terpukul dan sampai tidak mau makan (ayat 7,8). Kondisi ini mengisahkan cerita Hana yang sedih jiwa dan fisik goncang sampai pada batinnya pun menjadi terluka.

Proses konseling di sini yang dilakukan oleh Imam Eli sebagai konselor, namun terjadi sesuatu yang menarik ialah Iman Eli membiarkan Hana menangis sambil ia berdoa kepada Tuhan, ayat 10 “dengan hati pedih". Eli sengaja memberi peluang bagi Hana untuk membebaskan dirinya dengan membiarkannya menangis sambil berdoa. Dalam hal ini tidak banyak hal yang tampak dari tindakan Eli untuk menolong Hana, namun strategi konseling yang diterapkan oleh Eli ternyata cukup ampuh dalam 
membimbing Hana sampai ia menemukan jawabannya. Eli di sini hanya mengamati, menganalisa, dan mengambil kesimpulan (ayat 12-13). Meskipun perkataan Eli tampak salah duga dengan memberikan kalimat "Berapa lama lagi engkau berlaku sebagai orang mabuk" (ayat 14). Pertanyaan yang dilontarkan oleh Eli membuat Hana tersentak dan dengan tersentak bangkit berawal dari sinilah Hana mulai menemukan jati dirinya yang selama ini tidak ditemukan lagi. Hana dipulihkan secara menakjubkan.

Ayub merupakan contoh nabi yang mengalami goncangan jiwa yang melebihi dari tokoh-tokoh cerita manapun (Ayub 1:13-19). Ayub diterpa dari segala bidang kehidupan mulai dari meninggalnya anak-anak, ditinggalkan oleh istri tercinta, kehilangan harta bahkan penyakit dahsyat yang menimpa dirinya, dikucilkan oleh teman-teman dan semua orang. Depresi berat stadium tinggi yang dialami oleh Ayub menyebabkan Ayub mulai menyesali dirinya ${ }^{3}$ (Ayub 3). Dalam keadaan seperti ini muncullah Elifas, Bildad, Zofar dan Elihu orang-orang ini ternyata konselor yang tidak berhasil menyebuhkan dan memperbaiki keadaan yang Ayub alami justru mereka semakin menambah beban baru lagi bagi Ayub.

Dalam peristiwa ini pernyatan Allah terhadap Ayub yaitu menggunakan pendekatan menyeluruh semua aspek kehidupan, "The total recovery counseling approach". ${ }^{4}$ Pertama ajakan kepada Ayub agar Ayub keluar dari zona dirinya untuk melihat fakta yang penting dari apa yang sedang ia alami. Ayub diajak untuk menyelami bahwa dirinya sangat terbatas yang menyebabkan ia tidak dapat memahami segala sesuatu secara baik termasuk rencana Allah yang tersembunyi. Seterusnya Ayub diajak untuk melihat persoalan dari sudut pandang Allah sehingga ada keterbukaan hati untuk menerima yang sekarang sambil menanti apa yang diberikan setelah usai babak kesukaran yang dialaminya. Dengan sikap terbuka membuat Ayub mampu merendahkan dirinya dihadapan Allah dan memungkin pengalaman sukar berganti pada sukacita yang dan pada akhirnya Allah memberikan jawaban yang menakjubkan buat Ayub.

Sejak zaman para rasul, konseling telah ada di gereja sebagai kegiatan alami dalam kehidupan spiritual bersama. Bagaimanapun juga, Perjanjian Baru sendiri menyuruh para pemeluknya untuk saling menasihati "(Roma 15:14)" nasihatilah seorang akan yang lain "(Ibrani 3:13)" hiburkanlah seorang akan yang lain dan saling membangunlah kamu"(I Tesalonika 5:11). ${ }^{5}$

Rasul Paulus pun menulis, "Kita yang kuat, wajib menanggung kelemahan orang yang tidak kuat dan jangan kita mencari kesenangan kita sendiri "(Roma 15:1)" dan kalau pun seorang kedapatan

\footnotetext{
${ }^{3}$ Magdalena Tomatala, Konselor Kompeten (Jakarta: YT Leadership Foundation, 2003), 29.

${ }^{4}$ Ibid, 30.

${ }^{5}$ John F. MacArthur, Wayne A. Mack, Pengantar Konseling Alkitabiah (Malang: Gandum Mas, 2002 ), 19.
} 
melakukan suatu pelanggaran, maka kamu yang rohani, harus memimpin orang itu ke jalan yang benar dalam roh lemah lembut; sambil menjaga dirimu sendiri, supaya kamu juga jangan kena pencobaan. Bertolong-tolonglah menanggung bebanmu! Demikianlah kamu memenuhi hukum Kristus“(Galatia $6: 1-2)$.

Ajaran Alkitab seperti di atas dimaksudkan oleh Paulus agar setiap anggota jemaat wajib untuk memperhatikan satu dengan yang lain. Tentu Paulus bukan hanya sekedar menganjurkan kepada anggota untuk melakukan tindakan konseling tanpa dasar dan pegangan yang jelas. Paulus memberikan strategi standar sebagai pegangan dalam melakukan pelayanan konseling ini, apa yang harus dilakukan jika seseorang ingin membantu orang lain menyelesaikan masalah. Paulus berkata "jika seseorang ingin memimpin orang lain kepada jalan yang benar maka sebaiknya dengan lemah lembut, juga menjaga diri supaya jangan ia juga dibawa arus masuk dalam dosa” (Gal 6:1-2). Ayat ini berlaku sebagi standar kebenaran dalam upaya menolong orang lain sebagai konselor, bukan hanya bagi para pakar dan ahli teologi.

Dalam Perjanjian Baru terdapat banyak kasus yang dapat diangkat sebagai bagian dari praktik konseling. Kasus dalam Injil Yohanes 8:1-11 perjumpaan Yesus dengan orang-orang Farisi dan ahli Taurat. Kasus ini adalah kasus moralitas, wanita dalam kisah ini dituduh melakukan zinah dan ahli Taurat sedang mencoba Yesus dengan mengutip apa yang musa katakan yaitu "barangsiapa kedapatan melakukan zinah baiklah orang melemparkannya dengan batu” (ayat 5). Yesus sebagai konselor cukup membuat terkesima bagi banyak penantang, yaitu kelompok ahli taurat yang bertindak lebih suka "menjadi polisi yang mencari kesalahan Yesus" dari pada mereka pun harus membantu mengangkat orang lain yang nasibnya belum beruntung. Yesus memerintahkan "barang siapa yang tidak berdosa, baiklah ia yang pertama-tama melemparkan perempuan itu dengan batu" (ayat 6). Setelah Yesus berkata demikian satu per satu pun mereka pergi meninggalkan Dia. Yesus Sang konselor datang dengan membawa strategi yang tidak pernah ada di kepala banyak ahli Taurat yang hadir di tempat itu. Ia menjadikan perempuan ini sebagai model untuk merefleksikan kondisi bagi semua orang. ${ }^{6}$ Kolose 1:28, "Dialah yang kami beritakan, apabila tiap-tiap orang kami nasihati dan tiap-tiap orang kami ajari dalam segala hikmat, untuk memimpin tiap-tiap orang kepada kesempurnaan dalam Kristus.”

Dari kebenaran firman Tuhan di atas, di mana Yesus membawa setiap orang untuk melihat diri sendiri terlebih dahulu, dalam kisah di atas Ia menggiring kelompok orang Farisi untuk melihat diri sendiri, dan bertanya siapa saya, siapakah yang sebenarnya bersalah? Dari langkah yang dilakukan oleh

${ }^{6}$ Magdalena Tomatala, Konselor Kompeten (Jakarta: YT Leadership Foundation, 2003), 33. 
Yesus dapat tarik suatu kesimpulan bahwa penyembuhan itu di mulai dari dalam hati dan koreksi diri sendiri dan tanpa berupaya untuk mempersoalkan orang lain. Bahwa Kristus adalah sumber penyembuhan dari setiap masalah yang dihadapi manusia, karena Ia tidak hanya memberikan bimbingan, tetapi juga yang menyembuhkan orang yang dibimbing-Nya. Yang dibimbing harus dibawah kepada pengenalan kepada Kristus yang adalah sumber penyembuhan. Jika Kristus adalah sumber penyembuhan, maka dalam bimbingan Kristen, konselor dan segala cara bimbingan yang digunakan adalah media/alat dalam tangan Tuhan yang dipakai oleh Tuhan untuk memberikan pertolongan kepada orang yang dibimbing, kesembuhan datang dari Kristus. Bimbingan dilaksanakan tidak hanya menolong individu terlepas dari masalah yang dialaminya, tetapi sebagai upaya penanaman nilai-nilai Kristiani untuk hidup sesuai dengan kehendak Allah.

Dari penjelasan di atas bahwa sumber penyembuhan adalah Kristus, dan sebagai alat-Nya adalah konselor yang memberikan pertolongan kepada seorang yang akan ditolong.

\section{Pengertian Konseling}

Dalam Kamus Besar Bahasa Indonesia, kata konseling” diartikan pemberian bimbingan oleh yang ahli kepada seseorang dengan menggunakan metode psikologis, pengarahan, pemberian bantuan oleh konselor kepada konseli sedemikian rupa sehingga pemahaman terhadap kemampuan diri sendiri meningkat dalam memecahkan berbagai masalah, penyuluhan."7

Tulus Tu'u, mengartikan bahwa, "Konseling mengandung arti, membimbing, mendampingi, menuntun, dan mengarahkan." "Jadi, konseling merupakan suatu pelayanan yang dapat menolong konseli dalam bentuk melalui komunikasi. Dengan demikian bahwa seorang konselor dapat menolong orang keluar dari masalahnya yang ia hadapi dan mengalami suatu perubahan dengan ke arah yang benar. Yakub B. Susabda, mengungkapkan Bahwa,

Konseling adalah hubungan timbal balik (interpersonal relationship) antara hamba Tuhan (pendeta, penginjil) sebagai konselor dengan konselenya (klien, orang yang dibimbingan), dalam mana konselor mencoba membimbing konselenya ke dalam suatu suasana percakapan konseling yang ideal yang memungkinkan konsele itu betul-betul dapat mengenal dan mengerti apa yang sedang terjadi pada dirinya sendiri, persoalannya, kondisi hidupnya, di mana ia berada, sehingga ia mampu melihat tujuan hidupnya dalam relasi dan tanggung jawabnya pada Tuhan dan mencoba mencapai

\footnotetext{
${ }^{7}$ Kamus Besar Bahasa Indonesia, s.v. "Konseling"

${ }^{8}$ Tulus Tu’u, Dasar-Dasar Konseling Pastoral (Yogyakarta: ANDI, 2007), 22.
} 
tujuan itu dengan takaran, kekuatan dan kemampuan seperti yang sudah diberikan Tuhan kepadanya. ${ }^{9}$

Menurut Gary R. Collins bahwa, "Konseling adalah hubungan timbal balik antara dua individu, yaitu konselor yang berusaha atau membimbing dan konsele yang membutuhkan pengertian untuk mengatasi persoalaan yang dihadapinya." ${ }^{10}$ Dengan maksud konseli harus dipulihkan dari keberadaannya menuju suatu perubahan yang lebih baik.

Pdt. Carolis Huwae, S.Th dan Pdt. Dr. Rainner Scheunemann mengatakan, pertama, usaha dari konselor. Konselor adalah pemimpin yang dewasa dan melayani orang-orang yang tergantung oleh persoalaan hidupnya. Kedua, untuk menolong konseli. Konselor berperan untuk menolong konseli. Sambil mendengarkan konseli, ia harus menolong. Ketiga, melalui pembicaraan tatap muka. Cara menolong ialah dengan pembicaraan muka dengan muka. Harus ada pembicaraan di antara konselor dan konseli. Keempat, pertolongan diberikan agar konseli dapat menolong dirinya sendiri. Yang maksudnya di sini ialah bukan memberi nasehat atau mendorong konseli untuk mengikuti satu jalan yang dianggap baik oleh konselor, melainkan membiarkan dia memutuskan apa yang akan dia lakukan untuk menolong dirinya sendiri. Kelima, karena ada perkembangan pengertian mengenai perasaan-perasaan yang bertentangan dalam dirinya sendiri. Berarti bahwa dalam konseling, konseli sedikit demi sedikit melihat dan mengetahui keadaan kepribadiannya. $^{11}$

Konseling adalah pelayanan seorang hamba Tuhan untuk menolong orang lain melalui pembicaraan tatap muka agar orang itu dapat menolong dirinya sendiri karena adanya perkembangan pengertian tentang perasaan yang bertentangan dalam dirinya sendiri sesuai dengan kekuatan, takaran dan kemampuan yang Tuhan berikan kepadanya.

Dr. Magdalena Tomatala memperjelaskan pengertian Konseling adalah:

Pertama, konseling adalah suatu usaha untuk membantu konseli memperoleh pengertian dan bertanggung jawab atas dirinya sendiri. Kedua, Konseling adalah suatu usaha membawa konseli untuk mendapat pemahaman dan pengenalan akan dirinya sendiri, memperkaya konseli dalam mengambil keputusan, menghubungkan minat, bakat dengan perencanaan, pendidikan dan mengidentifikasikan keinginan serta kemampuannya untuk mencapai tujuan hidup yang berarti. Ketiga, Konseling adalah pemberian bantuan kepada konseli supaya dia dapat mengalami dan

\footnotetext{
${ }^{9}$ Yakub B. Susabda, Pastoral Konseling (Malang: Gandum Mas, 1985), 4.

${ }^{10}$ DR. Gary R. Collins, Konseling Kristen yang Efektif (Malang: Gandum Mas, 2007), 13.

${ }^{11}$ Pdt. Carolis Huwae, S.Th dan Pdt. Dr. Rainner Scheunemann, Metode Pelayanan Konseling Pastoral (Abepura: Sekolah Alkitab Malam Gereja Kristen Injili di Tanah Papua, 2004), 10-11.
} 
mengevaluasi segala situasi dan segala keterbatasannya dalam mengembangkan penyelesaian masalah atau persoalaan. Keempat, Konseling adalah hubungan individu antara konselor dengan konseli dalam upaya membimbing konseli agar ia dapat mengintegrasikan pengertian diri dengan situasi sehingga ia dapat mengambil keputusan dan menguasai dirinya secara bijaksana. ${ }^{12}$

Dari penjelasan yang telah dikemukan oleh berbagai penulis buku mengenai pengertian konseling, maka penulis dapat memberi pandangan bahwa konseling adalah suatu pelayanan yang bukan hanya menyampaikan konseling sebatas informasi saja, melainkan konseling yang menyatakan pola penyampaian pengetahuan yang bersifat mendidik, membantu orang untuk mengerti setiap keadaan yang dihadapinya, membantu dia untuk keluar dari masalah, menilai, misalnya memberikan buku bacaan selanjutnya menjelaskan dalam bimbingan, dan kemudian menerapkan informasi yang diterima secara relevan untuk menanggulangi situasi kehidupannya yang khusus.

\section{Bentuk-Bentuk Konseling ${ }^{13}$}

Seorang konselor harus mengenal bentuk-bentuk dari konseling yang di dalamnya dipercayakan Tuhan baginya, tugas dan panggilannya sebagai hamba Tuhan. Beberapa yang dikemukan oleh ahliahli yang dikutip Gary Collins mengenai bentuk konseling.

\section{Konseling Supportive (Mendukung)}

Gereja sebagai persekutuan keluarga Allah, banyak orang membutuhkan dukungan dari sesamanya (1 Korintus 12:12-27). Konseling ini diberikan bagi mereka yang mulai maju dan terbuka bagi persoalaan hidup, bukan dengan tujuan supaya dia bergantung penuh pada konselor, tetapi ditolong agar dia dapat menghadapi masalah-masalahnya dengan lebih konstruktif. Di dalam konseling supportive ini diajarkan untuk saling mendukung satu sama lainnya agar bertumbuh di dalam iman dan kematangan emosi sehingga dapat mengatasi persoalaan hidup yang ia hadapi.

\section{Konseling Confrontational (Konfrontasi)}

Tuhan Yesus sering mengkonfrontasi orang masalahnya terhadap dosa mereka, Ia mengkonfrontasi orang muda yang kaya karena ia banyak memikirkan tentang hartanya (Lukas 18:22), perumpuan samaria dengan perzinahannya (Yohanes 4:17-18), murid-murid-Nya kurang percaya (Matius 8:26; 14:31), dan pemimpin-pemimpin agama karena dosa mereka (Matius 12:34; 15:7-8; 23:23-33, Yohenis 8:44-45). Dalam hal ini konselor berbeda dengan Tuhan Yesus yaitu memberi kritik, tetapi bagi konselor Ia dengan kasih dan lemah lembut terpanggil untuk menolong konseli yang

\footnotetext{
${ }^{12}$ Dr. Magdalena Tomatala, Konselor Kompeten Pengantar Konseling Terapi untuk Pemulihan (Jakarta: YT Leadership Foundation, 2003), 3-4.

${ }^{13}$ Dr. Gary R. Collins, Pengantar Konseling Kristen yang Efektif (Malang: Seminar Alkitab Asia Tenggara, 2007), 74-78.
} 
menghadapi masalah dan kegagalannya agar datang kepada Yesus dan mengalami pengampunan-Nya. Hal yang penting yang disadari oleh konselor, yaitu bahwa konfrontasi tidak hanya terbatas pada diskusi mengenai dosa atau tingkah laku yang buruk saja. Jadi, konfrontasi menolong konsele untuk lebih memahami tindakan mereka sendiri, mendorong mereka untuk mendengar apa yang mungkin tidak mereka sukai, bahkan menolong mereka untuk melakukan langkah-langkah perbaikan yang selama ini mereka tolak.

\section{Konseling Educative}

Sebagian besar dari tingkah laku manusia telah dipelajari dari kecil. Demikian juga konseling sangat berhubungan dengan pendidikan, di mana orang datang untuk menemukan penjelasan teologis tentang hal-hal yang dihadapi dalam hidup ini. Dengan demikian seorang konselor harus mampu memberikan jawaban dari segala persoalaan manusia hanya dengan memohon hikmat dari Tuhan yang mempunyai segala sumber pengetahuan untuk menolong sesama. Jadi, seorang konselor harus percaya bahwa Tuhan dapat memakainya dalam pelayanannya untuk dapat menolong orang lain.

\section{Konseling Spiritual (Rohani)}

Pada dasarnya konseling Kristen adalah konseling rohani, sebab tugas ini berkaitan dengan amanat Agung berdasarkan di dalam (Matius 28:19-20; Roma 15:1; Galatia 6:1-2 ; 1 Tes. 5:14). Jadi, setiap konselor mempunyai tugas untuk membawa orang kepada Kristus untuk dapat menikmati hidup yang benar, (Yohanes 10:10), bahkan dapat memiliki hidup yang kekal (Yohanes 3:16). Untuk itu dalam menolong seseorang untuk mengerti arti dan tujuan hidup, seorang konselor yang saleh seharusnya menjadi konselor yang tidak ada bandingnya. Bahkan Gary Collins sependapat dengan Freud mengakui bahwa, hanya agama yang mampu menjawab pertanyaan mengenai tujuan hidup.

\section{Konseling Group (Secara Berkelompok)}

Dalam pelayanan Tuhan Yesus, Ia telah berbicara dengan banyak orang mengenai kebutuhan dan persoalaan-persoalaan mereka. Seringkali dalam konseling-Nya, Ia melibatkan beberapa orang sekaligus. Dalam perjalanan-Nya ke Emaus akan pembicaraan-Nya dengan Petrus, Yakobus dan Yohanes, akan diskusi-diskusi yang menyangkut kedua belas murid-Nya. Dalam jemaat mula-mula orang-orang bertemu dalam kelompok-kelompok untuk belajar, bersekutu, merayakan perjamuan kudus dan berdoa. Tentu saja dalam pertemuan persekutuan itu mereka membicarakan persoalanpersoalaan mereka dan kemudian saling tolong menolong dengan tiap kebutuhan mereka.

\section{Konseling Informal}

Konseling tidak selalu harus menggunakan kantor, tapi dapat dilakukan dirumah sakit, rumah, ruang pertemuan, atau bahkan di jalan. Kadang orang berpikir bahwa konseling informal kurang 
berguna, namun sebenarnya banyak gunanya, perlu diingat bahwa hampir semua konseling yang dilakukan oleh Tuhan Yesus adalah informal konseling, dan ternyata semuanya efektif.

\section{Konseling Preventive}

Konseling ini bertujuan untuk menghibur yang susah, menolong yang tertindas atau menolong orang dari kesulitan hidupnya, cara yang paling baik untuk memberikan konseling preventif adalah melalui khotbah di mimbar maupun ceramah-ceramah dan didasari dengan kebenaran firman Tuhan.

Dari semua bentuk konseling yang sudah di jelaskan di atas penulis mengambil suatu kesimpulan bahwa, konseling Spirituallah yang mampu untuk mengatasi persoalaan kehidupan manusia, mengapa? Karena dalam hidup ada masalah dan problem hidup pribadi, keluarga, hubungan dengan sesama, perilaku yang tidak benar dan tidak baik, semuanya diawali dengan akar katanya adalah dosa dan krisis spiritual. Ada orang yang memendam dosa cukup lama, sehingga hidupnya cukup kegetiran dan kepahitan. Ada yang mengalami keretakan hubungan dengan sesama karena tidak mampu memaafkan dan mengampuni, ada yang hidup tidak jujur dan tidak bertanggung jawab karena tidak peduli dengan prinsip-prinsip rohani." 14

Dengan demikian baik konseling edukatif, preventif, konfrontasi, personal, kelompok dan informal semua tujuan kepada konseling spiritual yang dapat menolong orang-orang untuk menyadari akan dosa menjadi akar dan penyebab penderitaan dan kepahitan hidup yang mereka alami.

\section{Kepribadian Seorang Konselor}

Kepribadian menunjukkan kualitas dalam pelayanan untuk seorang konselor, jadi, prinsip yang penting dan relevan bagi seorang konselor ia memiliki sikap kepribadian yang utuh, dapat menuntun orang-orang keluar dari masalah, sikap hati seorang hamba yang selalu siap sedia melayani serta memiliki hati yang mulia, melalui sikap kepribadian ini menentukan keberhasilannya di dalam pelayanan konseling, untuk itu perlu memiliki aspek yang baik yakni:

\section{Memiliki Aspek Kepribadian yang Utuh}

Seorang konselor ia harus memiliki suatu kepribadian yang utuh sehingga ia mampu mengarahkan orang lain yang akan ditolongnya. Dr. Magdalena Tomatala mengatakan bahwa“

Kepribadian seorang konselor harus jelas. Ia harus menemukan indentitas dirinya yaitu bahwa ia sepenuhnya yakin akan keselamatan di dalam Yesus Kristus bagi dirinya, di mana ia secara khusus telah menerima-Nya sebagai Tuhan dan Juruselamat pribadi (Efesus 2:8-9). Seorang konselor harus memiliki hubungan baik dengan Tuhan. Hubungan ini ditandai dengan sikap setia membaca firman

${ }^{14}$ Tulus Tu’u, Dasar-Dasar Konseling Pastoral, (Yogyakarta: ANDI, 2007), 188-189. 
Allah dan sedia untuk melakukan dalam hidup dan pengabdian sehari-hari (Bilangan 12:4-8). Konselor harus memiliki perasaan yang matang untuk menuntun orang lain dengan penuh kasih dengan sikap empati (Galatia 6:1,2). Ia harus memiliki keyakinan diri yang teguh sebagai dasar untuk merasakan beban orang lain sehingga ia sendiri tidak dihanyutkan oleh kenyataan yang dihadapinya (II Timotius 1:6-14). Ia harus memiliki sikap ramah dan sanggup berkomunikasi secara baik dengan disiplin diri yang tinggi (II Timotius 2:1-13). Ia harus bersandar sepunuhnya pada hikmat Allah Roh Kudus (Yohanes 3:17; Yes. 32:17, Galatia 5:15-21), bukan bersandar pada kekuatan diri sendiri. Ia harus memiliki damai sejahtera dari Allah yang akan dibaginya dalam melaksanakan bimbingan (Matius 5:9). Ia harus mempu mengendalikan perasaan sendiri tatkala berhadapan dengan konseli serta dapat menempatkan diri pada posisi yang baik sebagai konselor (Galatia 6:1-10; I Korintus 9:27). ${ }^{15}$

Apa yang telah dijelaskan di atas salah satu sikap seorang konselor harus berperan sebagai fondasi utama untuk melaksanakan tugas sebagai seorang konselor. Dalam buku Dr. Sofyan S. Willis mengungkapkan, "Bahwa kualitas kepribadian adalah semua kriteria keunggulan termasuk pribadi. Pengetahuan, wawasan, keterampilan dan nilai-nilai yang dimilikinya yang akan memudahkannya dalam menjelankan proses konseling sehingga mencapai tujuan yang berhasil."16

Dari penjelasan yang telah dikemukan di atas, bahwa seorang konselor harus memiliki kepribadian yang utuh dan sanggup menolong orang yang akan ditolong untuk keluar dari zona yang tidak nyaman yang ia hadapinya, dan membawa dia kepada suatu suka-cita, damai sentosa. Menjadi seorang konselor ia harus siap untuk menolong apa yang akan dijelaskan dibawah ini.

\section{Menjadi Penolong}

Untuk menjadi seorang penolong yang efektif kepada orang-orang yang mengalami masalahdalam hidupnya. Menurut Pdt. Dr. Mesach Krisetya, mengungkapkan ada beberapa langkah untuk menolong.

Pertama, Setting artinya mencari tempat yang aman untuk menolong klein, jadi, seorang konselor harus merahasiakan baik-baik semua yang dikatakan oleh konseli. Kedua, membangun kepercayaan sehingga suatu relasi akan tumbuh artinya bagaimana seorang penolong membangun percaya diri klien sehingga ia menceritakan permasalahannya lebih detailnya. Ketiga, mendengar dengan perhatian penuh, seorang klien mulai merasakan lebih baik hanya karena ia diberikan kesempatan

${ }^{15}$ Dr. Magdalena Tomatala, Konselor Kompeten Pengantar Konseling Terapi untuk Pemulihan (Jakarta: YT Leadership Foundation, 2003), 9-10.

${ }^{16}$ Dr. Sofyan S. Willis, Konseling Individual Teori dan Praktek (Bandung: Alfa Beta, 2004), 79. 
untuk menceritakan perasaannya dan percaya bahwa konselor sedang mendengarkan dengan penuh perhatian terhadap apa yang diceritakan olehnya. Keempat, menyediakan kenyamanan dan dukungan, ada banyak cara untuk membuat klein tahu bahwa konselor mendengar bukan hanya kata-katanya tetapi juga mengerti dan memahami, dengan menggunakan suara yang baik dan halus, sopan, tubuh, dan khususnya ekspresi wajah, bisa menunjukkan kalau konselor tertarik atau perhatian, jikalau seorang itu menangis, beri kepadanya tisu atau kalau dia takut, air untuk minun. ${ }^{17}$

Dari penjelasan di atas bahwa seorang penolong harus siap mendengar apa yang dirasakan oleh konselinya, sehingga ia merasa bahwa konselor mendengar dengan penuh perhatian kepadanya dan mengerti masalah yang dia hadapi.

Seorang penolong dalam pelayanan konseling ia harus memiliki beberapa prinsip-prinsip yakni;

Pertama, Nasihat, Roma 12:8 menasihatkan berarti menantang saudara-saudara seiman supaya senantiasa bertindak sesuai kehendak Tuhan. Konseling melibatkan tindakan-tindakan seperti menegur yang tidak tertib, menghibur mereka yang tawar hati, serta membela mereka yang lemah (I Tes. 5:14). Melalui karunia menasihati, para konselor dapat mendorong orang Kristen yang berdosa untuk meninggalkan dosa mereka, serta mempraktikkan yang benar, menghibur orang-orang yang hancur akibat kesulitan atau kesedihan, serta memperkuatkan iman mereka yang lemah. Kedua, Kebijaksanaan, adalah kemampuan untuk memahami bagaimana semua kebenaran Alkitab berlaku bagi isu-isu praktis dalam kehidupan sehari-hari. Ketiga, Pengetahuan, hal yang mendasar dari pengajar, serta konseling adalah pengetahuan. Pengetahuan adalah kemampuan yang dikaruniakan Tuhan untuk memahami semua misteri dari firman yang diwahyukan, semua kebenaran yang tidak diketahui terlepas dari pernyataan Tuhan. Keempat, Melayani, 1 Korinstus 12:28 (melayani), melayani merupakan suatu kemampuan pemberian Roh Allah untuk mengatur, mengawasi, serta mendorong sesama menyelesaikan suatu tugas. Mengingatkan banyak konseli yang hidupnya tidak tertib, terutama, mereka mengalami depresi, maka karunia melayani amat berguna bagi seorang konselor, untuk membantu konseli menertibkan kehidupan mereka supaya daapat memuliakan Tuhan adalah aspek yang penting dalam konseling alkitabiah. Kelima, Belas Kasihan, kasih kepada mereka yang sedang menderita, baik mereka menderita karena miskin atau penyakit fisik, atau mereka dikacaubalaukan oleh dosa. Dalam kesempatan ini mereka membagi beban dengan

\footnotetext{
${ }^{17}$ Pdt. Dr. Mesach Krisetya, "Diktat Konseling Pastoral” (Salatiga: Fakultas Teologi Universitas Kristen Satya Wacana, 2002), 39-45.
} 
seseorang yang dikaruniakan rasa belas kasihan. Di sini mereka membutuhkan suatu kelegaan dari beban yang mereka hadapi. ${ }^{18}$

\section{Memiliki Aspek Integritas}

Dalam Kamus Besar Bahasa Indonesia, "kata Integritas" mutu, sifat/keadaan yang menunjukkan kesatuan yang utuh sehingga memiliki potensi dan kemampuan yang memancarakan kewibawaan, jujur."19

Dasar dari kepribadiaan seorang konselor yang memiliki integritas rohani yang baik, jujur, setia, dan etika yang terpuji bukan karena memang ia baik. Integritas adalah Keterikatan yang kuat kepada moral atau prinsip artistik; kejujuran dan ketulusan; kebenaran; keutuhan, kelengkapan; kondisi tidak bercacat atau tidak rusak, kondisi asli yang sempurna. Integritas berarti konsisten dalam perilaku seseorang dalam setiap keadaan, termasuk saat-saat yang tidak disangka-sangka. ${ }^{20}$ Untuk mencapai integritas yang baik, maka disiplin hidup rohani dan perubahan ke arah yang positif adalah mutlak, sebab formasi rohani adalah vitalitas hubungan dengan Tuhan dan bermanifantasi dalam kepribadaian seorang pemimpin yang memiliki integritas. Pdt. Dr. Henoch F. Saerang, mengungkapakan bahwa integritas adalah, "Ketulusan hati, maksudnya dorongan dari dalam untuk berbuat baik sesuai dengan standar tertinggi pada situasi. Integritas terdiri dari kualitas yang jelas dan seimbang yang memampukan kita bereaksi benar pada setiap situasi. Integritas adalah reaksi yang bijak terhadap tekanan dari situasi yang sulit, khususnya di saat tahu tidak ada orang lain disekitar kita.”21

Untuk itu, kekuatan formasi rohani merupakan suatu dinamika bagi integritas dan kredibilitas diri seorang konselor ia harus mempunyai hasrat membawa tujuan, persatuan, intentitas, konsentrasi yang menjamin keberhasilan di dalam pelayanan.

\section{Peranan Roh Kudus dalam Konseling}

Pada dasarnya pelayanan konseling dan bimbingan adalah pelayanan Roh Kudus. Tidak ada satupun perubahan menetap dalam kehidupan manusia yang dapat dikerjakan oleh konselor sebagai manusia, semuanya adalah pekerjaan Roh-Nya dalam hati konseli. Roh Kudus adalah sumber utama, kekuatan dari konseling Kristen. ${ }^{22}$ Roh Kudus sebagai penuntun konselor Kristen untuk melayani sekaligus memulihkan, mengubah dan mendewasakan konseli. Roh Kudus disebut sebagai paraclete

\footnotetext{
${ }^{18}$ John F. Macarthur, Jr. Wayne A. Mack, Pengantar Konseling Alkitabiah (Malang: Gandum Mas, 2002), 388390.

${ }^{19}$ Kamus Besar Bahasa Indonesia, s.v. "Integritas"

${ }^{20}$ Blackaby. Henry\&Richard, Kepemimpinan Rohani, Gospel Press, Batam, 2005, hal.149

${ }^{21}$ Pdt. Dr. Henock F. Saerang, "Leadership Integritas" (Makassar: STT Jaffay, 2007).

${ }^{22}$ Dasar-dasar Keunikan Konseling Kristen Sepenuhnya diambil dari: Magdalena Tomatala, Konselor Kompeten (Jakarta: YT Leadership Foundation, 2003), 15-17.
} 
(pendamping) yang mengantikan Kristus bagi murid-murid-Nya. Semua konseling yang efektif tidak dapat dilakukan tanpa pimpinan dari Pareclete ini. $^{23}$

Pekerjaan Roh Kudus dalam konseling meliputi beberapa yaitu, pertama, Roh Kudus dapat menyatakan dosa manusia (Yoh 14:8). Kedua, Roh Kudus dapat mengajar orang tentang kebenaran (Yoh 14:26). Ketiga, Roh Kudus dapat menyaksikan Kristus (Yoh 15:26). Keempat, Roh Kudus dapat berkata-kata pada manusia Ia berkerja melalui hati dan mengerjakan dengan penuh kasih untuk menyadarkan manusia atas kehidupannya (Kis 13:2). Kelima, Roh Kudus dapat menolong dan menghibur dalam menghadapi kesusahan yang ditanggung, kehadiran Roh-Nya memberikan jalan keluar dan kesejukan hati dalam menghadapi kesusahan dan ketertindasan hidup (Yoh 14:20). Keenam, Roh Kudus diam dalam diri orang yang percaya, orang percaya dipimpin atau didiami oleh Roh Kudus dalam hatinya sehingga ia dimampukan dengan peka mendengar suara Tuhan yang dikerjakan Roh-Nya (Yoh 14:20). Ketujuh, Roh Kudus memimpin orang saleh (Kis 16:6).

John F. Mac Arthur dalam bukunya Pengantar Konseling Alkitab mengatakan bahwa, “Kelahiran baru adalah karya Roh Kudus yang berkuasa (Yoh. 3:8). Dan setiap aspek pertumbuhan rohani yang benar dalam kehidupan seorang beriman didorong oleh Roh Allah, menggunakan kebenaran Alkitab (Yoh. 17:17). "Hanya Roh kuduslah yang mampu melakukan perubahan-perubahan fundamental dalam hati manusia." 24 Peranan Roh Kudus sangatlah penting dalam pelayanan konseling dan dilandasi oleh Alkitab, Alkitab adalah standar final atau tolok ukur dari pelayanan konseling yang benar. Alkitab memberikan petunjuk, arah, tuntunan, serta hikmat bagi konselor untuk melaksanakan pelayanannya. Alkitab pun sekaligus menerangi dan memberikan perubahan oleh Roh Kudus, memperbaiki dan meneguhkan konseli menjadi lebih teguh, serta menuntun kepada hidup berkemenangan dalam Tuhan (2 Tim 3:15-17).

Jadi, Kristus lah fondasi yang kekal dalam pelayanan penggembalaan konseling. Konseling diletakkan atas kemuliaan pekerjaan-Nya yaitu kasih yang kekal. Kasih Kristus sebagai dasar kekuatan dan sandaran serta hikmat yang memotori sikap pelayanan konselor untuk menolong memberikan jawaban untuk menyelesaikan masalah konseli sebagai menusia yang berdosa sampai kepada pengenalan yang mendalam (1 Kor 13:1-3).

\section{Peranan Doa dan Firman Tuhan dalam Konseling}

Seorang konseling perlu mempunyai pemahaman yang benar tentang doa, dalam Alkitab memberi alasan mengapa harus berdoa yang dikemukan oleh John F. Macarthur, Jr. Wayne A. Mack ,

\footnotetext{
${ }^{23}$ Jay E. Adams, Andapun Boleh Membimbing (Malang: Gandum Mas, 1980), 23.

${ }^{24}$ John F. Macarthur, Pengantar Konseling Alkitabiah (Malang: Gandum Mas, 2002), 177.
} 
pertama, Tuhan yang memerintahkannya (Kol. 4:2 I Tim. 5:17). Kedua, Kristus memberi contoh sebuah doa (Mrk. 1:35; Luk. 6:12), ketiga, karena Kristus mengajar supaya berdoa (Mat. 6:5-9). ${ }^{25}$ Pada dasarnya doa adalah alat untuk berkomunikasi satu arah dengan Tuhan. "Doa dalam konseling adalah pemberi motivasi, penguji motivasi, pemberi informasi dan inspirasi dalam pelayanan konseling. Doa menghadirkan Allah dalam percakapan konseling. Doa juga merupakan tindak lanjut dalam pelayanan konseling. Doa adalah alat pemelihara hubungan dengan Tuhan, klien dan semua orang yang dikasihi. ${ }^{26}$

Dan firman Tuhan menjadi dasar setiap nasihat dan memberi solusi dalam mengakhiri konseling, di dalam 2 Timotius 3:16 mengatakan, "Segala tulisan yang diilhamkan Allah memang bermanfaat untuk mengajar, untuk menyatakan kesalahan, untuk memperbaik kelakuan dan untuk mendidik orang dalam kebenaran." Karena itu, seorang konselor harus berdoa terlebih dahulu agar Roh Kudus bekerja dalam kehidupan para konseli sehingga masalah mereka bisa diatasi, serta memberi ayat-ayat firman Tuhan sesuai dengan kebutuhan mereka.

Dari penjelasan di atas penulis dapat menyimpulkan bahwa, konseling adalah suatu proses dinamis yang berisi upaya memberi nasihat, petunjuk, peringatan, teguran, dorongan dan ajaran berdasarkan Alkitab.

\section{Pertumbuhan Gereja}

Allah yang Maha kasih menghendaki agar manusia yang tidak percaya itu kembali kepada-Nya melalui Kristus dengan tuntutan amanat Agung yang tentunya berdasarkan Injil Matius 28:19-20.

Berdasarkan Alkitab bahwa pertumbuhan gereja itu teologis yang dikehendaki oleh Allah. Bahwa Alkitab merupakan pegangan yang kokoh dan beriman kepada Yesus Kristus itu adalah mutlak untuk hal keselamatan yang kekal. Jadi, pertumbuhan gereja itu timbul karena adanya suatu keyakinan teologis. Pertumbuhan gereja memiliki tiga bentuk yaitu, pertama, pertumbuhan gereja secara biologis, kedua, pertumbuhan karena perpindahan anggota jemaat dari satu tempat ke tempat yang lain dan ketiga, pertumbuhan pertobatan karena kegiatan penginjilan bagi orang-orang yang belum percaya kepada Tuhan Yesus Kristus.”

Jadi, sikap orang Kristen ialah menjadikan setiap usaha untuk memenangkan semua orang yang terhilang bagi tubuh Kristus dan kemuliaan nama-Nya.

\footnotetext{
${ }^{25}$ John F. Macarthur, Jr. Wayne A. Mack, Pengantar Konseling Alkitabiah (Malang: Gandum Mas, 2002 ), 181.

${ }^{26}$ Pdt. Julianto Simanjuntak, Perlengkapan Seorang Konselor (Tangerang: Layanan Konseling Keluarga dan Karir (LK3), 2007), 23-24.
} 


\section{Pengertian Pertumbuhan Gereja}

Di dalam buku yang dituliskan oleh Harianto GP istilah Gereja berasal dari bahasa Portugis "Igreja", yang sama dengan Eklesia (bahasa Yunani), artinya, dipanggil keluar", kata "Eklesia" menekankan tiga hal yaitu, sidang (himpunan orang banyak), jemaat (bahasa Arab berarti, himpunan, rombongan atau pertemuan orang-orang), dan gereja. ${ }^{27}$

“Dalam Perjanjian Lama gereja disebut “orang-orang Kudus”. Bahasa Ibrani qahal (77 kali dalam PL), Qahal dipakai dengan suatu perkumpulan atau pertemuan tertentu di suatu tempat, sebagai suatu kumpulan jasmani dan tidak pernah digunakan untuk menyampaikan bahasan mengenai gabungan mistik para orang kudus sebagai kumpulan rohani dari orang-orang yang terpisah secara geografis. Dan dalam Perjanjian Baru gereja disebut Ekklesia berarti jemaat, perkumpulan orang-orang kudus, atau orang-orang Kristen." ${ }^{28}$ Gereja pada dasarnya adalah suatu perkumpulan, gereja adalah umat Allah, umat pilihan, persekutuan dari pada orang-orang yang telah menerima Yesus Kristus sebagai Tuhan dan juruselamat, telah menjadi tubuh Kristus. Jadi, Kristus adalah kepala gereja dan gereja adalah kabah Roh Kudus. Dan Peter Wagner, mengartikan pertumbuhan gereja adalah, "Segala sesuatu yang mencakup soal membawa orang-orang yang tidak memiliki hubungan pribadi dengan Yesus Kristus ke dalam persekutuan dengan Dia dan membawa mereka menjadi anggota gereja yang bertanggung jawab."29

Pertumbuhan gereja baik kuantitas maupun kualitas hanya pertumbuhan kepada tubuh Yesus Kristus saja dan pertumbuhan gereja adalah sebuah perubahan.

\section{Makna Pertumbuhan Gereja}

Istilah pertumbuhan gereja menurut C. Peter Wagner diperkenalkan oleh Donald McGavran pada awal pelayanannya sebagai seorang utusan Injil di India. Lalu pandangan C. Peter Wagner "Dimensi pertumbuhan gereja merupakan sebuah asumsi teologis yang menjadi pedoman dari pengertian pertumbuhan gereja ialah Tuhan menghendaki agar domba-dombanya yang hilang ditemukan dan di bawah kembali kepadanya." ${ }^{30}$ Dalam konsep ini, terjadinya suatu pertumbuhan gereja karena kehendak Tuhan di dalamnya. Dalam bukunya Ron Jenson dan Jim Stevens mengungkapkan, bahwa "Pertumbuhan gereja adalah kenaikan yang seimbang dalam kuantitas, kualitas dan kompleksitas organisasi sebuah gereja lokal. Ini merupakan salah satu kunci untuk memahami proses

\footnotetext{
${ }^{27}$ Harianto GP, Mission For City (Bandung: Agimedia, 2006), 125.

${ }^{28}$ John F. Walvoord, Gereja dalam Nubuatan (Surabaya: Yakin, 1984), 15.

${ }^{29}$ C. Peter Wager, Gereja Saudara dapat Bertumbuh (Malang: Gandum Mas, 1976), 11.

${ }^{30}$ C. Peter Wagner, Strategi Pertumbuhan Gereja, (Malang: Gandum Mas. n.d), 24.
} 
yang menyebabkan pertumbuhan gereja." 31 Atau dengan kata lain, bahwa pertumbuhan gereja meliputi segenap upaya untuk menempatkan umat-Nya Allah yang "Kudus dan tak bercela dan tak bercacat di hadapannya“" (Kol. 1:22) dalam pengertian ini maka gereja dilihat sebagai suatu perhimpunan orang yang memperlihatakan eksistensi, solidaritas, serta pebedaannya dari perkumpulan-perkumpulan lainnya."32 Dengan demikian, bahwa pertumbuhan gereja memberi sumbangsih bagi dinamika perkembangan gereja-gereja Tuhan, yang sesuai dengan prinsip-prinsip Alkitabiah.

\section{Dimensi Pertumbuhan Gereja}

Pertumbuhan gereja yang sehat dan terus-menerus bersifat multidimensi. Dalam bukunya Rick Warren menjelaskan dimensi pertumbuhan gereja adalah, "Setiap gereja perlu bertumbuh akrab melalui persekutuan, bertumbuh sungguh-sungguh pemuridan, bertumbuh kuat melalui ibadah, bertumbuh melalui pelayanan dan bertumbuh luas melalui penginjilan." 33 Dalam Kisah Para Rasul 2:42-47, dari kelima segi pertumbuhan ini digambarakan dalam gereja mula-mula di Yerusalem. Jadi, orang Kristen yang mula-mula mereka bersekutu, saling membangun, berbakti dan menyembah Allah, melayani dan menginjili. Dan sebagai akibatnya dalam ayat 47 berbunyi, "Dan tiap-tiap hari Tuhan menambah jumlah mereka dengan orang yang diselamatkan." Maksud dari ayat ini bahwa Tuhan menambah pertumbuhan ketika gereja melakukan bagiannya sebagai tanggung jawab dengan gereja.

\section{Hubungan Konseling dan Pertumbuhan Gereja}

Dalam sebuah gereja tidaklah lengkap tanpa pelayanan konseling, bila seorang gembala mengabaikan pelayanan konseling bagi anggota jemaatnya, maka berbagai jenis pelayanan yang lain pun akan terkena dampaknya, oleh karena itu, penulis akan menjelaskan kaitan pelayanan konseling yang menghasilkan pertumbuhan gereja baik secara kualitas dan kuantitas yakni;

\section{Korelasi Antara Konseling dan Pertumbuhan Gereja Secara Kualitas}

Pelayanan konseling sangatlah dibutuhkan di dalam gereja. Tujuan pelayanan konseling pastoral yang dilakukan oleh seorang gembala jemaat adalah menciptakan suatu transformasi atau perubahan di dalam hidup jemaat yang dilayaninya. Perubahan yang dimaksudkan adalah perubahan seseorang ke arah yang positif atau lebih baik. Jemaat yang memiliki kebiasaan-kebiasaan yang kurang baik atau pun tidak selaras dengan nilai-nilai kekristenan, melalui pelayanan konseling penggembalaan diharapkan dapat menjadi domba-domba yang tidak tersesat dan berjalan menurut keinginannya sendiri tetapi hidup takut akan Tuhan.

\footnotetext{
${ }^{31}$ Ron Jenson dan Jim Stevens, Dinamika Pertumbuhan Gereja (Malang: Gandum Mas, 1996), 8.

${ }^{32}$ John Stott, Satu Umat (Malang: Semenari Alkitab Asia Tenggara, 1992), 8.

${ }^{33}$ Rick Warren, Pertumbuhan Gereja Masa Kini (Malang: Gandum Mas, 2000), 55.
} 
Gereja yang memahami fungsi pelayanan konseling serta menerapkannya dengan benar akan menghasilkan pertumbuhan yang berkualitas bagi jemaatnya. Pertumbuhan yang berkualitas ini akan terlihat pada kualitas kehidupan anggota jemaat, di mana setiap permasalahan yang muncul dapat diatasi dengan memakai metode pelayanan konseling yang dibangun di atas prinsip-prinsip Alkitab. Dalam buku Dr. Magdalena Tomatala mengatakan bahwa, "Gereja yang bertumbuh secara sehat perlu mempertimbangkan dengan serius pengadaan pelayanan konseling Kristen bagi anggota-anggota jemaatnya dan Penerapan pelayanan konseling Kristen hanya dapat dilakukan apabila para pelayan Tuhan di dalam jemaat memperoleh pelatihan khusus dalam bidang konseling Kristen". ${ }^{34}$ Oleh sebab itu, perlu seorang gembala mengadakan suatu pelayanan yang lebih efektik dalam meningkatkan kualitas hidup kerohanian bagi anggota jemaat dengan cara yakni:

\section{Melalui Pembinaan Rohani}

Konseling merupakan salah satu bagian untuk meningkatkan kualitas kerohanian anggota jemaat yang di layani. Seperti yang dikemukakan oleh Yakub Susabda bahwa "Melalui pelayanan konseling maka kosele betul-betul dapat mengenal dan mengerti apa yang sedang terjadi pada dirinya sendiri, persoalannya, kondisi hidupnya, di mana ia berada, sehingga ia mampu melihat tujuan hidupnya dalam relasi dan tanggung jawabnya pada Tuhan dan mencoba mencapai tujuan itu dengan takaran, kekuatan dan kemampuan seperti yang sudah diberikan Tuhan kepadanya. ${ }^{35}$

Setiap manusia diciptakan Tuhan dengan maksud dan tujuan tertentu yang berujung pada kedewasaan dalam Kristus. Seperti yang diungkapkan rasul Paulus dalam Kitab Efesus 4:13, "Sampai kita semua telah mencapai kesatuan iman dan pengetahuan yang benar tentang anak Allah, kedewasaan penuh, dan tingkat pertumbuhan yang sesuai dengan kepenuhan Kristus. Oleh karena itu, manusia harus berusaha untuk memahami dan bertanggung jawab atas tujuan Allah bagi dirinya.

Pelayanan konseling sangat dibutuhkan untuk mendampingi, mengarahkan, menuntun, anggota jemaat untuk keluar dari persoalan hidupnya. Jadi, pembinaan rohani tidak terlepas dari pelayanan konseling yang efektif dan berkesinambungan dalam pelayanan pembinaan rohani kepada anggota jemaat.

\section{Melalui Perkunjungan}

Dalam pelayanan perkunjungan yang dilaksanakan oleh seorang gembala jemaat adalah untuk memberikan perhatian sepenuh kepada anggota jemaat. Pelayanan perkunjungan yang di jelaskan di

\footnotetext{
${ }^{34}$ Dr. Magdalena Tomatala, Konselor Kompeten Pengantar Konseling Terapi untuk Pemulihan (Jakarta: YT Leadership Foundation, 2003), v.

${ }^{35}$ Yakub B. Susabda, Pastoral Konseling (Malang: Gandum Mas, 1985), 4.
} 
atas merupakan pelayanan ke rumah-rumah anggota jemaat. Peter wongso mengatakan bahwa, "Perkunjungan adalah yang pertama, mempererat persahabatan. Kedua, memperdalam kenalan, secara langsung, mengenai keadaan dan kebutuhan rohani dan jasmani setiap jemaat." 36 Perkunjungan salah satu cara yang baik untuk mengarahkan kerohanian anggota jemaat, dengan cara perkunjungan dari rumah ke rumah untuk menguatkan iman percaya mereka kepada Yesus Kristus. N. Mimery mengatakan bahwa, "Dengan mengunjungi jemaat sang gembala membina hubungan erat dengan domba-bomba. Hubungan antara kedua pihak merupakan unsur yang penting dengan sang gembala jemaat mengetahui keadaan jemaatnya dan barulah ia dapat melayani mereka secara efektif.”37

Dari penjelasan di atas bahwa, pelayanan perkunjungan memberikan penguatan kepada anggota jemaat sehingga mereka merasa diperhatikan, ditolong untuk dikeluarkan dari masalah yang mereka hadapi melalui percakapan konseling.

\section{Melalui Bimbingan}

Pelayanan bimbingan adalah salah satu cara untuk membimbing seorang yang memiliki masalah dalam kehidupan dan membawa dia kepada pertobatan. Winkel W.S mengatakan bahwa, "Bimbingan adalah bantuan diberikan oleh orang yang mempunyai syarat dan mampu untuk menolong orang lain menata hidupnya sendiri, mengembangkan pandangannya, mengambil keputusan sendiri, dan memikul bebannya sendiri." 38 Bimbingan berarti memberikan bantuan kepada seseorang dalam membuat pilihan secara bijaksana sehingga ia sanggup mengatasi masalah yang akan datang kepadanya. Dalam pelayanan bimbingan tidak terlepas dari pelayanan konseling, seorang konseling harus sadar bahwa orang yang dibimbing terus-menerus dibina kerohaniannya sehingga ia mampu menjalankan kehidupannya dengan baik.

Berdasarkan penjelasan di atas bahwa, pelayanan pembinaan rohani, pelayanan perkunjungan, pelayanan bimbingan semuanya tidak terlepas dari pelayanan konseling yang dilakukan. Melalui pelayanan yang dilaksanakan merupakan suatu proses untuk menguatkan setiap orang yang memiliki masalah dan membawa mereka untuk keluar dari masalah yang mereka hadapi dengan penuh kemenangan dan sukacita.

\section{Korelasi Antara Konseling dan Pertumbuhan Secara Kuantitas}

Ada berbagai macam strategi dalam meningkatkan pertumbuhan gereja secara kuantitas dan salah satunya melalui pelayanan konseling. Adapun korelasinya yakni;

\footnotetext{
${ }^{36}$ Peter Wongso, Theologia Penggembalaan (Malang: Seminari Alkitab Asia Tenggara, 1991), 78.

${ }^{37}$ N. Mimery, Rahasia Tentang Penggembalaan Jemaat 53.

${ }^{38}$ Winkel W.S, Bimbingan dan Konseling di Sekolah Menengah (Jakarta: PT. Gramedia, 1985) .
} 


\section{Pengaruh Terhadap Jumlah Kehadiran dalam Ibadah}

Salah satu terjadinya jumlah kehadiran dalam ibadah ialah mengadakan pelayanan konseling yang dilakukan oleh seorang gembala jemaat, bertumpu dari tujuan dan manfaat pelayanan konseling penggembalaan yang menciptakan pertumbuhan gereja secara kuantitas, Pdt. Dr. Daniel Ronda mengatakan bahwa, konseling memberi pemahaman kepada orang/jemaat tentang arti menerima orang lain dan dirinya sendiri itu adalah bagian dari konseling. ${ }^{39}$ Pelayanan konseling yang dilakukan oleh seorang gembala dalam jemaat akan membawa suatu perubahan dalam hidup anggota jemaat yang bertahun-tahun tidak bergereja karena memiliki problem hidup, dengan di jalankan pelayanan konseling sehingga mereka terbuka dengan masalah yang mereka hadapi dan pada akhirnya mereka bertobat dan dipulihkan.

Dengan penjelasan di atas, apabila pelayanan konseling dijalankan bersama-sama dengan pelayanan penggembalaan, maka akan menghasilkan suatu perubahan yang berdampak positif serta menghasilkan pertumbuhan gereja secara jumlah kehadiran dalam ibadah karena ada kesadaran dari orang yang dibimbing.

\section{Petobat-Petobat Baru Melalui Pelayanan Konseling}

Dalam perumpamaan-perumpamaan yang Yesus ajarkan Ia mengumpamakan diri-Nya sebagai gembala dari kawanan domba. Sebagai Gembala yang baik dan bertanggung jawab Yesus datang mencari yang tersesat dan terhilang dari kawanan. Dalam Injil Lukas 19:10, "Sebab Anak Manusia datang untuk mencari dan menyelamatkan yang hilang."

Kata "terhilang" bukan saja mencakup mereka orang Israel saja tetapi juga kepada non-Israel. Pdt. Julianto Simanjuntak mengatakan bahwa, Konseling adalah Amanat Agung untuk membawa orang kepada Kristus berdasarkan Matius 28:19 karena itu pergilah jadikanlah semua bangsa murid-Ku dan baptislah mereka dalam nama Bapa, Anak dan Roh Kudus. ${ }^{40 "}$ Dan inilah salah satu tugas yang diembankan oleh Kristus kepada gereja yakni mencari mereka yang belum diselamatkan bagi Kristus.

Dari hal di atas maka pelayanan konseling harus mengambil peran dalam penjangkauan bagi mereka yang terhilang di luar Kristus.

Pdt. Dr. Daniel Ronda mengatakan bahwa, "Gereja bertumbuh dengan baik karena ada pelayanan konseling yang baik. ${ }^{41}$ Tulus Tu'u mengatakan bahwa, "Pelayanan konseling pastoral perlu dilakukan untuk menjangkau pihak yang terpinggirkan. Jadi gereja bertanggung jawab memberikan

\footnotetext{
${ }^{39}$ Pdt. Dr. Daniel Ronda, Seminar Regional Counseling Workshop (STT Jaffray : Makassar 2008).

${ }^{40}$ Pdt. Julianto Simanjuntak, "Seminar Regional Counseling Workshop" (Makassar: STT Jaffray, 2008).

${ }^{41}$ Pdt. Dr. Daniel Ronda, "Seminar Regional Counseling Workshop” (Makassar: STT Jaffray, 2008).
} 
perhatian dan melakukan pelayanan pastoral bagi mereka." 42 Pelayanan konseling sangat berguna bagi pengembangan pertumbuhan gereja secara kuantitas di mana pelayanan konseling ini dapat di pakai untuk pelayanan perkunjungan dengan cara pendekatan, kepada mereka yang kumpul kebo maupun kepada mereka yang nikah beda agama, jika pelayanan ini berhasil terjadi pertumbuhan gereja.

Dari penjelasan di atas dapat dikatakan bahwa konseling memiliki hubungan erat dengan penginjilan. Juga konseling sebagai salah satu sarana penginjilan yang efektif bagi mereka yang tidak bergereja atau mereka yang masih hidup di luar Kristus. Konseling perlu dijalankan bersama-sama dengan pelayanan penginjilan. Dengan demikian sangat jelas keterkaitan antara konseling dan pertumbuhan kuantitas dalam jemaat.

\section{KESIMPULAN}

Pertama, pelayanan konseling penggembalaan secara umum merupakan suatu proses pembimbing, dan pengarahan oleh seorang ahli yang bertindak sebagai konselor dengan cara menyampaikan nasihet, petunjuk, peringatan, teguran, dorongan, dan ajaran dalam upaya menangani masalah dari konseli yang berhubungan dengan pelayanan penggembalaan.

Kedua, pelayanan konseling dalam penggembalaan adalah untuk menuntun, membimbing, mendampingi, mengarahkan dan menguatkan setiap masalah yang ada untuk diselesaikan.

Ketiga, pelayanan konseling penggembalaan sebagai konseling Kristen di dasarkan atas tutunan kuasa Roh Kudus dan firman Tuhan serta doa.

Keempat, pelayanan konseling penggembalaan didasarkan pada Alkitab Perjanjian Lama mau pun dalam Perjanjian Baru, dari tujuan pelayanan konseling ini yakni membimbing orang-orang kepada keselamatan kepada Yesus Kristus.

Kelima, pelayanan konseling penggembalaan adalah kepada warga gereja, anggota jemaat, orang yang belum terjangkau.

Keenam, Gereja memerlukan seorang gembala yang memiliki karunia penggembalaan, dan mempunyai integritas diri dalam pelayanan.

Ketujuh, pelayanan konseling penggembalaan merupakan salah satu dari beberapa pelayanan untuk meningkatkan pertumbuhan Gereja.

Kedelapan, Gereja membentuk satu tim dalam pelayanan konseling serta melibatkan anggota jemaat yang memiliki potensi/skill untuk menjalankan pelayanan konseling penggembalaan.

${ }^{42}$ Tulus Tu’u, Dasar-Dasar Konseling Pastoral (Yogyakarta: ANDI, 2007), 61. 


\section{KEPUSTAKAAN}

Kamus

Tim Penyususn Kamus Pusat Pembinaan dan Pengembangan Bahasa. Kamus Besar Bahasa Indonesia, Jakarta: Balai Pustaka, 1995.

\section{Buku-Buku}

Adams, Jay E. Andapun Boleh Membimbing. Malang: Gandum Mas, 1980.

Blackaby. Henry\&Richard, Kepemimpinan Rohani, Gospel Press, Batam, 2005

Collins, R, DR. Gary. Konseling Kristen yang Efektif. Malang: Gandum Mas, 2007.

Djadi, Jermia. Peran Pastoral Konseling Bagi Pertumbuhan Jemaat. Ujung Pandang: Makalah, 1994.

Doug Self \& Bruce Larson, Paul Anderson. Pelayanan Penggembalaan yang Ideal. Malang: Gandum Mas, 1996.

Rainner Scheunemann dan Carolis Huwae. Metode Pelayanan Konseling Pastoral. Abepura: Sekolah Alkitab Malam Gereja Kristen Injili di Tanah Papua, 2004.

GP, Harianto. Mission For City. Bandung: Agimedia, 2006.

Jim, Stevens dan Ron Jenson. Dinamika Pertumbuhan Gereja. Malang: Gandum Mas, 1996.

Jr. Wayne, A. Mack, John ,F. Macarthur. Pengantar Konseling Alkitabiah. Malang: Gandum Mas, 2002.

Krisetya, Mesach. Diktat Konseling Pastoral. Salatiga: Fakultas Teologi Universitas Kristen Satya Wacana, 2002.

----------. Konseling Pastoral. Salatiga, Fakultas Teologi Universitas Kristen Satya Wacana, 2002.

Mimery N. Rahasia Tentang Penggembalaan Jemaat. Bandung: Mimery Press, 1989.

Ronda, Daniel. Seminar Regional Counseling Workshop. STT Jaffray: Makassar, 2008.

Saerang, F Henock. Leadership Integritas. Makassar: STT Jaffay, 2007.

Simanjuntak, Julianto. Perlengkapan Seorang Konselor. Tangerang: Layanan Konseling Keluarga dan Karir (LK3), 2007.

------------. Seminar Regional Counseling Workshop. STT Jaffray: Makassar, 2008.

Susabda, Yakub B. Pastoral Konseling. Malang: Gandum Mas, 1985.

Stott, John. Satu Umat. Malang: Semenari Alkitab Asia Tenggara, 1992.

Tomatala, Yakob. Konselor Kompeten Pengantar Konseling Terapi untuk Pemulihan. Jakarta: YT Leadership Foundation, 2003. 
Tu’u, Tulus. Dasar-Dasar Konseling Pastoral. Yogyakarta: ANDI, 2007.

Wagner, C. Peter. Gereja Saudara Dapat Bertumbuh. Malang: Gandum Mas, 1976.

-------------. Strategi Pertumbuhan Gereja. Malang: Gandum Mas, 1976.

Walvoord, John F. Gereja dalam Nubuatan. Surabaya: Yakin, 1984.

Warren, Rick. Pertumbuhan Gereja Masa Kini. Malang: Gandum Mas, 2000.

Wayne, A. Mack John F, MacArthur. Pengantar Konseling Alkitabiah. Malang: Gandum Mas, 2002.

Willis, Sofyan S. Konseling Individual Teori dan Praktik. Bandung: Alfa Beta, 2004

Winkel, W.S. Bimbingan dan Konseling di Sekolah Menengah. Jakarta: PT. Gramedia, 1985.

Wongso, Peter. Theologia Penggembalaan. Malang: Seminari Alkitab Asia Tenggara, 1991. 